\title{
How to talk about languages: the venues metaphor
}

\author{
Jim O’Driscoll \\ University of Huddersfield \\ Tel: +44 1484473568 \\ Email: J.O’Driscoll@hud.ac.uk
}

\begin{abstract}
This paper advocates a new perspective on languages. It begins by demonstrating that, the occasional disavowals of sociolinguists notwithstanding, the lens through which we in the $21^{\text {st }}$ century, both specialists and laypeople, view languages is predominantly biological. It then suggests that this biological metaphor is conceptually unhelpful and potentially socially deleterious. The bulk of the paper presents and explores the metaphor of social venues as a more productive and empowering alternative: the presentation is through the example of language choice in multilingual settings; the exploration touches on a range of language contact and macro-sociolinguistic phenomena.
\end{abstract}

Keywords: language ideology; language choice; language contact; linguistic anthropology; conceptual metaphor

\section{Introduction}

In this paper, I oppose two conceptual metaphors for languages. One of these is biomorphic. It can be expressed as LANGUAGES ARE LIFE-FORMS. After showing that this is the metaphor by means of which both the academy and the wider public habitually think about and talk about languages (Section 2), I offer reasons why its prevalence needs to be contested (Section 3). However, it is virtually impossible to talk about abstract concepts without recourse to metaphor (Lakoff and Johnson 1999: 28). Moreover, trying out alternative metaphors is a way to "avoid being imprisoned by [our] own semiotic categories" (Makoni and Pennycook 2007: 17). So, in the rest of the paper, I offer the alternative spatial metaphor, LANGUAGES ARE VENUES. I introduce and develop this metaphor through the example of language choice in multilingual settings (Sections 4-5) and then apply it briefly across a wide sweep of linguistic topics (Section 6). I conclude with a perfunctory evaluation (Section7).

This paper, then, is an essay in the ideology of languages. Note the plural. It is widely recognised that, while language is an innate human capacity, languages are human inventions. However, there is a tendency among linguists to blur this distinction by using language as shorthand for a language, as in Sampson's (1980: 34-56) chapter "language as social fact", Blommaert's (2008: 291-292) critique of "textual practices [which] can reduce language to an artefact" and most of Seargeant's (2009) examples of the metaphor "LANGUAGE IS A POSSESSION". Perhaps this is one reason why the social significance of 
languages-as-inventions remains largely unrecognised (see Makoni and Pennycook 2007). This paper is an exploration of this significance. It takes its cues from Le Page's (1988) call for introspection about common stereotypes of a language (and subsequent calls for similar problematisation), my own attempts to understand the pattern of language choice in one multilingual setting in the mid 1990s and Blommaert's (2003: 608; $2005 \mathrm{~b}$ ) more recent calls to set aside the concept of languages in favour of those of language varieties and repertoires. As its title indicates, I have not taken up Blommaert's call literally. True, there is a good case for rejecting the notion of languages, not only from his ethnographic sociolinguistic viewpoint but also from a more conventional sociolinguistic one (Hudson 1996: 30-38) and from a purely descriptive-linguistic one (Harris 1990, 1998). However, "those factors that are believed to be true have definite consequences, whether or not they are initially and empirically true" (Fishman 1994: 84 on the subjective power of perceived distinct languages). So in this paper, rather than throw languages out, I offer one way of 'reconstituting' them (Makoni and Pennycook 2007) in a manner that allows the greater flexibility implied by 'language varieties' and affords a greater place for repertoires than heretofore.

\section{The resilience of the biomorphic metaphor}

The metaphor LANGUAGES ARE LIFE-FORMS has long ceased to be the dominant scholarly paradigm that it was in the $19^{\text {th }}$ century (see e.g. Sampson 1980: 13-28). However, I argue in this section that it remains deeply entrenched in our approach to languages. The discoursal variety of the evidence allows me to claim that it has a "global systematicity" (L. Cameron 1999: 129) which thus has the power to structure our thoughts and actions (Lakoff and Johnson 1980). In doing so, I do not refute Seargeant's (2009) identification of a metaphor which presents languages as possessions; but I argue - as the examples which he himself quotes demonstrate - that the biomorphic metaphor is the more pervasive. Examples of its use sometimes index a more specific collective variant, LANGUAGES ARE BIOLOGICAL ORDERS (typically species), or a more specific individual variant, LANGUAGES ARE INDIVIDUAL LIFE-FORMS, but often seem to apply to both levels.

First, and in keeping with D. Cameron's (2007) evidence for the "matter-of-fact acceptance" of the metaphor in the mainstream media, we may note that the most readily available means of classifying a language is probably genetic (e.g. Indo-European, West Germanic) rather than typological (e.g. SVO, analytic). ${ }^{1}$ Next, there is the habitual distinction between 'living' languages and 'dead' or 'extinct' ones. Like the difference between marked and unmarked graves, languages such as Latin and Sanskrit are 'dead' whereas those without an accessible writing system are 'extinct' (e.g. Lockwood 1972:

\footnotetext{
${ }^{1}$ In February 2012, I conducted an email straw poll of (mostly) linguists. When asked to imagine that, on being discovered as a linguist at a party, they were faced with the question; "What kind of language is [language X]?", and assuming they wanted to come across as authoritative but intelligible, almost twice as many respondents opted for a genetic description as for a typological one. Details can be provided on request.
} 
71; Crystal 1997: 302-303, 318- 326, 329). The same automatic use of the collective variant of the metaphor can be seen in the phrase 'endangered languages'.

Notwithstanding these default usages, the metaphor has not undergone semantic bleaching, as witnessed by the frequent employment of hyponyms of 'death'. It has, for example, long been a matter of public debate in Ireland whether the dramatic decline of Irish during the $19^{\text {th }}$ century was 'murder' or 'suicide'. Such usage exemplifies the productivity of the individual variant of the metaphor. Leonard's (2008) characterisation of the Miami language as not dead but 'sleeping' is another. That of the collective variant is illustrated by terms such as 'linguistic genocide' (e.g. Skutnabb-Kangas 2000).

Statistical evidence of the dominance of the biomorphic metaphor can be found from searches on Google Scholar. ${ }^{3}$ These suggest that to refer both to languages no longer in use and also to the process of this cessation, terms indexing the metaphor (e.g. dead languages, an extinct language, language death, linguistic genocide) are used about 10 times more frequently than the sum of any other feasible noun phrases (e.g. a disused language, abandoned languages, language disappearance, language demolition). The figures for reference to the possibility of such cessation (e.g. endangered languages, a dying language versus e.g. a vanishing language, decaying languages) are almost as decisive. Only with reference to stabilisation or increase in use are terms indexing the biomorphic metaphor (e.g. language revitalisation, language rebirth) exceeded in number by other terms, but this is because of just one phrase (language maintenance).

The metaphor also appears in some macro-sociolinguistic traditions. Models for the mid- $20^{\text {th }}$ century practice of sociolinguistic profiling included the term 'vitality' as one of a language's possible attributes (e.g. Stewart 1968; Bell 1976) and macro-sociolinguists of most stripes have uncritically discussed this attribute ever since. Similarly, although the field known as ecolinguistics is explicitly opposed by Mühlhausler (2011: 199) to the view of languages as "related to one another like biological species", and even though the limitation of the lexeme 'ecology' to physical (i.e. non-cultural) matters is one which this approach contests (Fill and Mühlhausler 2001: 6-8), for as long as this contestation fails, both terms inevitably encourage a view of languages as life forms (Pennycook 2004).

The biomorphic metaphor, then, is to a large extent second nature to us and most of the time goes unnoticed. Occasionally, though, it is foregrounded. One example in a work aimed at a wide readership is the history of the English language by the British cultural commentator Melvyn Bragg. After introducing English as having been 'seeded' in England as a number of dialects which then 'grew' into the language we recognise today, Bragg is explicit that although "this is not how professional linguists see it ... the language itself, in my view, can be seen as a living organism" (Bragg 2003: ix). His account proceeds to encode this view ad nauseam.

\footnotetext{
2 The assignment of 'endangered' to the biological category in this context is based on a search of the British National Corpus, which reveals that the most frequent and most statistically significant collocate of this word is 'species', and that other highly significant collocates are 'habitats' and 'breeds'; that is, terms in the domain of ecology. For this information, much thanks to Brian Walker.

${ }^{3}$ Precise figures produced by these means are of course totally unreliable. However, the results are so overwhelming as to nullify these inadequacies. Full details of the figures, the searched terms and the method of search are available from the author on request.
} 
In more specialist work, I know of only one serious entertainment of languages as species (Laponce 1993). Linguists, as Bragg recognises, are wary of the metaphor. Nevertheless, there are characterizations of the English language in modern times as Tyrannosaurus Rex (Swales 1997; O'Driscoll 2002a; Tardy 2004) or, more inventively, a cuckoo or Frankenstein's monster (Phillipson 2008). And there are numerous similes explicitly likening languages to species (e.g. Nettle and Romaine 2000: 43, 79), a practice which Tsitsipis (2006: 256) decries but admits is what "every well-meaning scholar and activist generally does". Such usages of the biological source domain are not intended as theoretical building blocks. But they point up the ease with which it can be drawn upon. Indeed, it is so strongly rooted that even those who might prefer to avoid it find that they can't. Crystal (1988: ix), for example, introduces his overview of English (again for a wide readership) by likening a language to a country and is explicit that "a language does not grow like a plant or a person". And yet, in introducing the three parts of his book, he describes Part I (on structure) as 'anatomical' and Part II (on situated use) as 'physiological'. Likewise, in their introduction to an early journal volume devoted to 'Language Death', Dressler and Wodak-Leodolter (1977: 5-11) caution that this phrase does not mean they view languages as organisms, but they justify it on the grounds that it conveys the high drama involved in disappearing languages and also that the possible alternative term (language decay), "has already been seized upon by purists and language critics" (Dressler and Wodak-Leodolter, 1977: 5).

But perhaps the most telling indication of the entrenchment of the biomorphic metaphor is that other scholars who have critically discussed terms arising from it have not done so with a view to jettisoning it. Instead, they either stand above it in order to develop their own theoretical perspective (e.g. McEwan-Fujita 2011) or discuss alternatives within it. Thus Denison (1977) professes suspicion of it but nevertheless can only suggest that 'suicide' is often a more suitable term than 'death' to denote the cessation of use of a language. Edwards (1986) and Dorian (1994) reject both 'murder' and 'suicide' as unhelpfully emotive terms but do not question the term 'death' from which they derive. Nor does Leonard (2008) - he only argues for its redefinition. Skutnabb-Kangas (2000), despite arguing that the biomorphic metaphor is often inapplicable (2000: 71, 218-219), trenchantly defends her use of 'linguistic genocide', 'language murder', even 'extermination' of languages, because these terms point up the (frequently violent) actions of outside agencies in causing the cessation of use of a language (2000: xxxi-xxxiii, 222, 365-374). Debates about how to label such cessation, then, revolve around who or what is responsible for the loss of life - not whether it is helpful to conceive of the phenomenon that way in the first place. I suggest in the next section that it is not.

\section{Problems with the biomorphic metaphor}

The biomorphic metaphor is beguiling. It can provoke hours of instructive musing on the nature of languages and (see e.g. Pennycook 2004: 215) has the power to engage and raise awareness. It is even possible to argue it should be taken seriously (see Sampson 1980: 26-33, 241-242). However, Pennycook (2004) makes several excellent observations regarding its ultimate untenability, and both he and Cameron (2007) have convincing arguments of the dangers it poses for our conceptualisation of language use in 
general. In addition, I suggest, its entailments that languages have intrinsic properties and at least some degree of agency have a disturbing corollary by which we language users are relegated to dependent status, either as parasites feeding off the languages and needing to accommodate to their characteristics and foibles, or as otherwise empty vessels to be filled. In this cosmology, languages don't belong to people. Rather, people belong to languages. (See Errington 2008: ch.7 and Duchêne and Heller 2007 for similar critiques of the metaphor.) Such a view is not merely unattractive; it is at least facilitative of a number of socially deleterious attitudes and practices.

\subsection{The reduction of linguistic diversity}

In the last 50 years or so, the world has seen increased use of a very few recognised languages and a decrease in use, sometimes to zero, of a startlingly large number. When languages are seen as species, this development is too easily accepted as a 'natural' one which there is no point in fighting. Thus popular discourse explains the spread of the use of English by referring to its supposed intrinsic suitability for the modern world (see O’Driscoll 2002a for examples). As numerous scholars have shown (e.g. Phillipson 1992; Pennycook 1994), this discourse is not only facilitative of the global decrease in diversity but also wrong; there are human agents out there causing these developments. The biomorphic metaphor encourages us to forget, or just not see, this rather obvious fact. (See May 2001: 3-4 for a similar argument.)

I want here to take this argument further. As has often been asserted, albeit with a tendency to overstate the 'fit' between a language and a world view (e.g. Harrison 2007; Evans 2010) and a tendency to orientalism (observed by Cameron 2007), one worrying consequence of this reduction in linguistic diversity is the impoverishment of humanity's intellectual resources. An entailment of the biomorphic metaphor - that languages are discrete entities - can assist in this impoverishment by distracting us with trifling aspects of language contact. For example, the myriad interpolations of etymologically English items into other European languages receive an unwonted degree of attention. Much of this supposed invasion is largely a mirage (O'Driscoll 2002a; House 2003). And yet there is much popular and institutional reaction to it, stemming from a concern for the purity of languages fostered by the biomorphic metaphor. National language academies too often concentrate on this misguided protectionism instead of promoting the products of their linguistic communities, some of which may turn out to be of inestimable value but otherwise lost to the world as a result of international scholarship becoming monolingual English. (See O'Driscoll 2002a for suggestions that two such bodies of work have been effectively lost in the last two decades.)

\subsection{Barriers to social equity}

Posner (1991) identifies a series of widespread assumptions of homogeneity regarding languages. One of these is that formal variety within any one language is viewed as essentially aberrant. It would be stretching a point to lay the blame for the acceptance of such homogeneity as both the norm and optimal entirely at the door of the biomorphic metaphor. But there is no doubt that viewing languages as inherently distinct entities whose purity must be protected abets it (see Watts 2011). It is through this notion that the 
main evil of prescriptivism, by which all forms deemed non-standard are simultaneously decried as sub-standard, is maintained. The metaphor encourages an attitude requiring language users to accommodate to languages, which are presumed to exist in their own right in some ideal form. Of course, this ideal form is the form it takes in the mouths and keyboards of the powerful.

\subsection{The inhibition of interaction across language communities}

A further assumption of homogeneity identified by Posner (1991) is that every speech event should take place in only one language. He shows that, in Europe at least, this norm is applied even when participants can understand each others' languages but are not very fluent in expressing themselves this way, so that the most logically efficient means for them to communicate would be to each speak in their own (different) languages. This assumption, together with the assumption that language community membership is optimally restricted to just one, Posner believes, amounts to "a political maxim [which has] brought great harm to mankind" (1991: 128) and whose psychological result is that people experience life among speakers of another language and conversing in a language other than their own as unpleasant and best avoided. One may add that this ideology of homogeneity surfaces in interaction as almost wilful failure to understand the speech of 'foreigners' (Shuck 2004; Chand 2009). A consequent further assumption, moreover, is that language contact entails language conflict, a belief sometimes presented as sociolinguistic orthodoxy (see O'Driscoll 2000: 141-144). Self-consciously cooperative cross-cultural interactants therefore sometimes attempt to play down their differences (thereby further diminishing linguistic diversity - see Section 5.1 below.)

Again, it cannot be claimed that these obstacles to cross-cultural interaction stem entirely from the biomorphic metaphor. Nevertheless, the view of languages as separate, distinct entities with lives of their own fosters an unwarranted expectation of difficulty and friction. After all, parasites find it very difficult to jump species. And there is something unseemly about the attempt to do so.

\section{Languages as social venues: the interpersonal effects of language choice}

Implicit in the biomorphic metaphor is a relationship between languages and their users in which the former are the more active participants. A basic scenario of the collective variant (LANGUAGES ARE BIOLOGICAL ORDERS), for instance, is that languages compete for territory (us). In the rest of this paper, I propose and explore an alternative metaphor in which this scenario is impossible because the languages are the territories; they are the buildings and other recognisable areas and structures of the built environment in which people find themselves in the company of other people. The metaphor can be expressed as LANGUAGES ARE VENUES, where 'venue' denotes a place recognised as one where people gather and interact. ${ }^{4}$

\footnotetext{
${ }^{4}$ The term 'venue' is deliberately more specific than 'place' because this latter word does not entail interaction. It also connotes something more rigid and instantly observable than 'meeting-place' because it stands principally for a recognised human construct called a language, not just an instance of language-use. However, it has fuzzy boundaries. See the start of section 7.
} 
This section introduces the metaphor by applying it to an account of language choice in interaction across language communities. ${ }^{5}$ Imagine a prototypical dyad whose members regard themselves as native speakers of different languages. Let's say it comprises you and me. We need to talk. Logically, we have three possible ways of doing so: my language, your language or a link language (i.e. one which neither regards as his/hers). In terms of the metaphor, it is a matter of where we meet: my place, your place or a public place (e.g. pub, café, restaurant, city square).

\subsection{The Café}

If we meet at a café, we are on neutral ground where norms of behaviour are imposed by others. As a result, we involve ourselves in comparatively few interpersonal obligations. We also have the opportunity to demonstrate our ability to deport ourselves in the big, wide world and, unencumbered by domestic tell-tale signs, we can choose which aspects of ourselves to project and which to leave at home.

A similar amalgam of neutrality, worldly display and lack of engagement obtains when we talk in a link language. We both (try to) follow the constitutive rules of the medium, safe in the knowledge neither has custodianship over these rules. Instrumentally, it might be easier to use my language (you might be fluent in it), but a link language allows us to keep our distances with less effort. Mazrui (1975: 73-74) notes that British colonial administrators in eastern Africa often used to insist on using Swahili to Africans, even if neither of them knew it well and both knew English well, because it was a way of maintaining social distance.

\subsection{Entertaining at home}

If we meet at my place, the above symmetry does not apply. Both social norms and my greater familiarity with the surroundings give me control over the general tenor of our encounter. This is also a more intimate world in which you are privy to information about me which you would not otherwise learn. Similarly, when we use my language, my greater fluency (and often mutual expectation) gives me conversational dominance. But at the same time, you have the opportunity to learn more about the 'real' me than if we were talking in a link language.

The result of these two imbalances in power, the one in ability to call the interactive shots, the other in interpersonal knowledge, is that we are tied in to several role obligations. At my place, I should make you feel welcome by indicating that you need not behave too circumspectly, anticipating your needs and suitably adapting my domestic habits and manners, but not with so much obvious effort that you feel like an intruder. Likewise, I will indicate that you don't need to be too tentative about your performance in my language, volunteer prompts when you appear to be at a loss and modify my native

\footnotetext{
${ }^{5}$ This account follows O'Driscoll (2001) in that it does not appeal in the first instance to social structure, psychological needs or social values for explanation (i.e. the three approaches to this topic identified by Fasold 1984: 180-212). Rather, it appeals to the immediate interpersonal effects of a choice of language. The case study in the following section does appeal to these phenomena, but within the interpersonaleffects framework which has been introduced.
} 
language habits, avoiding too much colloquialism and articulating clearly, but not too obviously unnaturally.

And you, as guest, should behave with due circumspection, follow house rules and ask if you not sure of these, just as you would normally defer to my native knowledge of the language, follow my lead with regard to its structural patterns and ask for help when in doubt. But again, this should not be overdone - a guest who behaved with exaggerated diffidence would be a poor guest, just as a non-native speaker who concentrated too overtly on the formal acceptability of his/her linguistic performance would make a poor conversational partner.

\subsection{Different kinds of café}

The above account concerns the variable of ownership (mine, yours or neither). The other major variable is status. Just as there are large, plate-glass-fronted cafés in the centre of town which everybody knows and many frequent, so there are languages with a high profile in the world, regularly used by large numbers of speakers. Using such a link language or meeting at such a café says relatively little about our relationship.

At the other extreme are little basements tucked away in side-streets. People walking past one of these may realise something is there but not be sure what. Others may know of its existence but not know where it is. Only a few people know both of these things, and fewer still ever go inside. If we meet there, we enact a special affinity to each other. In the same way, there are marginal languages of whose existence most people are unaware. Even people regularly exposed to one may not know what it is. Some know of its existence but do not recognise it when they hear it. Again, only a few recognise both its existence and its forms, and fewer still are able to use these forms. If we use this variety to talk to each other, we likewise enact a special affinity.

\subsection{Different kinds of residence}

Now imagine I live in a very large residence (L1) with so many occupants that visitors are always popping in. With so much coming and going, habits are arranged accordingly (e.g. the front door is left unlocked, visitors help themselves to drinks) and the most regular visitors have had some influence on the household's codes of conduct, so that authority for these does not lie as exclusively with residents as it does in the stereotype host/guest scenario outlined previously. There will be a tendency for the two of us to regard this residence as our 'natural' meeting place, with neither of us so aware of ourselves as 'host' and 'guest'. This residence, while classifiably private, has to some extent become a surrogate café. These same circumstances obtain when my language is very widely used. We tend to regard it as our 'natural' medium and do not see our roles as 'native' and 'foreign learner' as so salient. This language, while still associated with native-speakers, is seen as also belonging to the world at large. Groups of non-natives who regularly use it among themselves develop their own norms. In such circumstances, our encounters have relatively little interpersonal significance.

At the other extreme, if we meet in my tiny, unassuming dwelling (lesser-used, marginal language) that few non-residents know, the sense of significance of the occasion, of mutual obligations and intimacy, will be felt very strongly indeed. I will be very much 
in control of the proceedings. If you become a frequent visitor, each visit will be a confirmation of our relatively intimate relationship because my household gets so few other visitors.

\subsection{Selves in 'public' houses}

The account above shows the language used both indexing and affecting personal relations. It also indexes and affects self-presentation. Consider again the large, muchvisited house (lingua franca) where I reside. On some occasions, you may enter at my behest, on others at that of other household members. And once inside, you interact not only with many of us but also with other visitors. Clearly, this world is not a very private one. Your presence there indexes not only, or even mainly, your affiliation to my particular cultural background; it also demonstrates social competence in the big wide world.

This projection of a cosmopolitan identity at such a residence applies also to me. I can identify with my inherited background, but not very closely. The frequent presence of guests means that part of this background is common knowledge. In addition, the existence of large numbers of my fellow household members means that individual differences in behaviour between us are observable. Thus the selves projected by nativespeakers of a lingua franca become partly disconnected from their ethnic backgrounds. Their knowledge of its norms does not merely identify them as belonging to this background but also, like L2 speakers, demonstrates their ability to move in the wider world.

\subsection{Selves in 'private' cafés}

When we meet at a café, we both present ourselves as prepared to 'face the world'. However, in a small, back-street café, it is not simply the 'world' that we face. We are in a home from home, and, unlike the large town-centre cafés, the owner or members of his/her family will often be present. Thus when we meet there, we also make an affiliative statement. After all, you cannot just 'find yourself' in one of these cafés as you might at a central-square café. You have to decide to go there and your presence implies some special enthusiasm.

Likewise, any L2-L2 interaction in a lesser-used language involves some kind of proactive decision to do so. While people the world over learn a language such as English out of purely instrumental motivation, they only learn a lesser-used language out of integrative motivation. Therefore such interaction, while it still projects a cosmopolitan self, is also a nod in the direction of an adoptive ethnicity.

\subsection{Comment}

The account given in this section is prototypical and has consequent limitations. Particular encounters will always involve circumstances which nuance both participant relation to the language/venue and also its status in the world at large. Perhaps, for example, I am regular at the café at which we meet (fluent in this L2) while you have never been there before (an elementary-level learner), so that I have some of the 
responsibilities and dominance associated with meeting at my home. As for the latter, every café has its own unique ambience, even large quotidian ones (see Section 5.2 for an example of such differentiation). These differences will have their own interpersonal and self-presentational resonances. In addition, this account, because it focuses on the effects of the use of one language rather than another, ignores the fact that in many cases a lack of shared codes means there is only one realistic 'choice' of language. But the central point remains - and is, indeed, strengthened by these variations and possible limitations of choice - that the particular language used for communication has immediate affective and behavioural effects on participants, according to the status of that language and participants' relation to it, and that these effects come to light when languages are described in terms of venues but not when they are seen as life-forms.

\section{Languages as social venues: a case study of language choice}

This section illustrates and develops the above application of the venues metaphor through an account of the linguistic habits and preferences of the students of Europa College in Bruges (Belgium), a residential, postgraduate community of some 300 students and 40 staff from all corners of Europe, in the mid 1990s. In terms of the venues metaphor, Europa College was the town in which the students and staff lived. ${ }^{6}$

\subsection{The overwhelming preponderance of English and French}

In Europa-College-town at this time, about $90 \%$ of informal contact between members of different language communities took place in English or French premises. Remarkably little took place in the many other premises (some 25 native languages were represented) and that which did was in a domestic setting (involving a native speaker), never a public one (mutual L2).

English/French preponderance was to be expected because these were the premises used for public functions (the two official college languages), so use of them indexed citizenship, they were among the largest households ${ }^{7}$ in town (had many native speakers) and familiarity with other premises (ability in other languages) was limited. However, none of this explains the sheer, overwhelming extent of the preponderance because there were other factors that one would have expected to militate against it: the authorities offered facilities and funds to promote diversity; one other residence in town - the German one - had even more residents (and yet only rarely entertained visitors); almost half the students did have at least some familiarity with premises other than their own or

\footnotetext{
6 The official names of this institution are College of Europe and Collège d'Europe. The name used here reflects local informal usage at the time. A full account of this case study can be found in O'Driscoll (1999), a summarised version in O'Driscoll (2002b). Because it is possible that habits have changed since the time of the study, the description here is couched in past tense.

${ }^{7}$ It may be noted that in referring to L1 groupings as households, I raise a provocative etymological connection with the biomorphic view of languages as organisms occupying eco-niches. The eco-prefix derives from the Greek word 'oikos', which denotes 'household'. However, I hope it is clear that my households neither occupy eco-niches nor are eco-niches themselves. They occupy spaces built by human action alone and delineated by human consensus alone.
} 
the English or the French and, crucially, were generally keen to make social calls on the residents of these dwellings (talk to people in their own language).

However, along with this enthusiasm for paying visits went a notable lack of enthusiasm about being visited. Visitors who came round unannounced (who initiated conversation in their interlocutor's language) tended to be tolerated rather than welcomed and sometimes even got the door slammed in their faces (their choice was language was bluntly rejected). Here lies the explanation. Both wanting to be the guest and not the host, students often ended up in a café - English or French - as a compromise. Thus the habits of households other than the English and French ones remained largely screened off from the community at large - and public establishments other than the English or French remained empty shells. A sad tendency to lack of diversity was thereby promoted. ${ }^{8}$

There were only two exceptions to this general preference for avoiding socialising at home. One of these was the Czech and Polish next-door neighbours, who were happy to chat over the garden fence (each use their own language). The other emerges in Section 5.3 below.

\subsection{English versus French as public establishments}

Status is a matter not only of size but also of quality. And in this respect, the English and French venues exhibited marked divergences. In aggregate, the French public establishment was not as well-frequented as the English one. But this relative lack of custom was not through lack of esteem. In fact, it was an object of aspiration. People were generally very positive about the thought of going there. It had a rather exclusive image: the hoi poloi could go to the self-service cafeteria (English), but people who eat at a proper restaurant (French) are people to be reckoned with. However, all its rules of etiquette made it somewhat intimidating. Given the possible face loss of transgressing one of these, it often felt easier to just go down the road to the cafeteria instead.

Therefore, a curious pattern of customer-flow pertained. People were more likely to go to the restaurant when: there was nobody else there (a dyad interacting without overhearers), so that there would no other witnesses to any faux pas; they were with someone who professed not to care about matters of etiquette; they were with a particularly close friend or they were drunk, when the oppressive formality of the surroundings could be offset by the informality of the relationship or the mood. At the other extreme, two strangers meeting for the first time overwhelmingly preferred the cafeteria, where there was much less risk of being judged on your manners (linguistic performance).

\subsection{English versus French as private residences}

\footnotetext{
${ }^{8}$ O'Driscoll (2002b) explains this curious mixture of sociability and secrecy by identifying a dominant ideology which regards the display of one's own domestic particularity (the use of one's own language) as inherently unsociable and uncooperative. To some extent, this ideology is a reaction to the situation pertaining in many other towns (language communities such as EU bodies), in which members insist on conducting their business from home, even if communication therefore has to take place via messengers (interpreters).
} 
French household members were generally proud of their abode and often keen to show it off. They were the only householders in town who would sometimes invite people back home (initiate conversation in their own language) enthusiastically. Inside the French residence, the décor was rather formal and there were many rules of behaviour, transgressions of which hosts invariably pointed out. Some guests experienced this atmosphere and practice as impressive, aesthetically pleasing and hospitable; it's nice to know where you stand. Others found it intimidating, stuffy and belittling.

A visit to the English residence was less fraught. Less care appeared to be taken with the state of the place (the English language has no Academy) and household members seemed content to let visitors behave almost any way they liked. In one way this was very attractive. You did not feel the need to be on your best behaviour. In another way, it could be irritating. You could visit hundreds of times and still not feel you really belonged. And since English householders did not willingly invite you back home, the only way to visit was to go around there uninvited. (This more casual, 'impersonal' tenor of interaction in English premises generally involves social networks of a markedly loose-knit type which, according to the classic study by Milroy (1980), leads to greater susceptibility to linguistic change. Thus we may suggest an operational explanation [i.e. a reason beyond mere institutional pressure] for the greater formal variation - and tolerance of it - to be found in English than in French around the world.)

\section{Developing the venues metaphor: some other applications}

In this section, I suggest some other areas of language study in which the venues metaphor might usefully be applied. There are (at least) three angles from which to consider a venue: what it's made of and looks like (physical structure); what kinds of things go on there (activities); who uses it and has rights over it (occupied property).

For reasons of space, the exploration here is sketchy, concentrating on the last of these perspectives. The activities perspective I pass over completely, save to point out that this aspect, the stuff of the ethnography of communication, is subject to wide variation from venue to venue (some exemplification of which is given in the English/French comparisons above). As for physical structure, I note only that the venues metaphor offers a better defence against notions of innate superiority / inferiority than the biomorphic metaphor because a structure can always be extended. True, some structures (pidgins) could not bear any more weight (can convey only relatively gross meaning distinctions) and therefore can only be extended laterally (range of reference). However, as we know, once permanent residents move in (creolisation), structural adjustments are made and vertical extension (finer-grained meaning distinctions) becomes possible.

Normally, the more people reside at a venue, the more extensions and outbuildings will be constructed. Some of these agglomerations, even if immediately adjacent and of basically identical structure (mutual intelligibility is virtually 100\%) may come to be regarded as different addresses (e.g. Swedish and Danish), while others whose structures are less similar and further apart (so that mutual intelligibility is patchy) continue to be regarded as components of a single venue complex (e.g. English in the $21^{\text {st }}$ century). Alternatively, the peripheral structures can become more important than the original core. Latin was once a venue which attracted many new tenants who gradually built their own adjacent dwellings (French, Spanish etc.) and was eventually abandoned as a residence. 
However, it did not become derelict. For almost a millennium, it served as an important public venue throughout Europe. By now, the public functions have been taken elsewhere. But the Latin edifice has been preserved and now functions as a museum.

More frequently, a much vacated property starts falling into disrepair. It ceases to attract visitors, so that its remaining residents are forced to leave it to interact with nonresidents and there is little time or perceived need for its upkeep, leading to further dilapidation, making it progressively less attractive as a habitation, so that people whose families have lived there for generations move out. (See Garafanga 2010 for a modern, micro-level example.)

At this point, it is helpful to introduce Rampton's (1995: 336-344) deconstruction of the notion of native speaker into three elements: expertise, which is something learned rather than innate, relative rather than absolute and partial (thus divesting native-speaker proficiency of its mystical connotations), inheritance, which results from birth and upbringing, and affiliation, which is the result of personal predisposition. In the oftassumed monolingual norm, a resident (native speaker) is born where his/her parents are long-term residents (Rampton's inheritance) and spends his/her whole life in that same residential compound. Naturally, this is the place with which s/he identifies (Rampton's affiliation) and the only one in which s/he becomes adept at conducting the general business of life (Rampton's expertise). Only occasionally may s/he venture beyond (encounter other languages), and then only for special purposes (e.g. formal language lessons, tourism). But in fact, this is not a true summary of most people's lives anywhere in the world. True, the majority may spend their formative years chiefly in one place which they regard as home. But they find themselves quite often in other venues from an early age, one or more of which they may be told also belongs to them (as when children who have learnt one variety at home get prescribed a different one at school). In other cases (as with the children of immigrants at school), they learn that such belonging is either beyond them or must be earned by developing demonstrable expertise. In either case, as they get older, they learn to use the resources of a range of venues with varying degrees of proficiency. Their experience of these various venues will be in varying circumstances, and of course the resources themselves vary across venues. As a result, many find themselves most comfortable (affiliating) and/or capable (expertise) in one venue for some purposes but more so in another for others - sometimes more so than in their original home (inheritance). (For examples of this 'truncated multilingualism', see Blommaert 2005a: ch.8.)

Viewing Rampton's analysis through the lens of venues also emphasises that a person's relation to a language is radically influenced by social consensus and power. In the biomorphic metaphor, this relation is pre-ordained because inheritance subsumes expertise (and is known as 'native-speaker intuition'), both of which are ascribed by nature rather than society. With venues, on the other hand, rights to occupation and ownership are a matter of social custom and/or law. There is great variability in who is recognised as a household member by other occupants (see Giles, Bourhis and Taylor 1977; Allard and Landry 1986) or by the world at large (Makoni and Pennycook 2007: 12). There are even cases where a sort of honorary household membership is claimed by people who have never lived in the residence concerned (see e.g. Wicherkiewicz 1995; Vieru-Dimulescu 2008: 16). 
In Rampton's terms, the problem for the remaining occupants of depopulating residences is that both expertise and affiliation tend to take them to other venues. If they wish to keep their inheritance, they need to find ways of renovating the premises (so that it is re-associated with expertise) and of making it more attractive both as a habitation and as a venue for visitors (so that there is greater affiliation).

Thus the venues metaphor goes some way to dissolving the supposed tension between the individual rights of a minority-language speaker to adopt and use the dominant language and the group rights of a minority to retain their language. It shows this is not an either/or issue. People are mobile. It is perfectly possible to have unimpeded access to the big public venues (the individual rights) while remaining secure in the tenure of one's home (the group rights) and its upkeep. It is even possible to argue that frequent use of the public venue can strengthen the affect attached to, and therefore the upkeep of, 'home' (House 2003: 561). If people do find themselves having to make a choice between being stuck at home or shut out from it, this is the result of more-or-less conscious external social forces, not supposedly inexorable biological ones.

This notion of personal mobility (polyglot ability) also casts in a curious light a tendency in discussions of lesser-used languages to remark on the numbers of monoglot users. For example: "Navaho ... is currently in decline, with monolingual speakers aging and declining in number" (Mesthrie and Leap 2009: 265-266). This implication that language maintenance depends on such individual inability is not unusual. In the context of a survey of the prospects for Celtic languages, Crystal (1997: 305) remarks that "some 5,000 people claim to be monolingual in Irish". That the first quote comes from a sociolinguistics textbook and the second from an encyclopaedia testifies to the entrenchment of this assumed correlation. Here is another example: the inhabitants of two villages in southern Italy "have maintained their Francoprovencal language, Faetar: virtually everyone ... speaks this variety on a daily basis. Since at least the 1970s, however, all but the oldest are bilingual in Italian" (Nagy 2011: 368, my italics). The 'however' here presupposes a contrast between bilingualism and language maintenance. The venues metaphor questions the assumption. If you are housebound, you can't go out and obtain the resources necessary for your household, nor can you meet people and invite them back home. And indeed, Nagy's evidence can be read as showing that it is partly because a great deal of re-sourcing has occurred that the tiny Faetar residence continues to thrive. ${ }^{9}$

In the $21^{\text {st }}$ century, however, what seems crucial to the viability of any venue is a separate address (official recognition as a language). This means communications can be delivered directly (e.g. EU documents translated into that language variety) and easier access for potential visitors (language lessons will be available) than if access can only be gained via the central adjacent residence (lessons only in the standard variety). The residence now known as Scots, resembling and adjacent to that of English, once had its own address. History, however, has seen it lose its self-contained status (it is not an

\footnotetext{
${ }^{9}$ The perspective presented here may appear to contradict the social-network orthodoxy that the continued existence of lesser-used, low-status varieties demands relative lack of contact with the outside world. However, as Milroy \& Milroy (1992) have pointed out, it is the "weak ties" with the outside world which allow network members access to resources. These ties foster change in specific linguistic forms within these varieties but they do not necessarily lead to the disappearance of the varieties themselves.
} 
official EU language). It is now just a wing of the English residence. What has happened to Scots has happened to many other households over the last few centuries when a neighbouring household indulges in language standardisation. The apparent success of this process has provoked modern attempts to replicate it for decaying properties. These, however, can run into trouble when there are several recognisably distinct households (varieties) within it because the choice of one of them as that whose norms are made explicit - and therefore by implication to be followed - makes members of others feel like strangers in their own homes. (This phenomenon has been noted with regard to numerous lesser used European languages: Dorian 1987; Wardhaugh 1987: 110; Rayfield 1990; Green 1994; Jaffe 2007; Ó hIfearnáin 2008.)

The modern world is one in which everyday domestic habits (language use) are subject to an astonishing degree of rigid formalisation. In order to retain their indigenous territories (language varieties), smaller households are obliged to indulge in previously alien activities such as building walls and fences (to demarcate 'a language') and installing certain homogenising practices within them (standardisation) so that their territory is recognised by the outside world and accorded title deeds. (See Blommaert 2008 and the volume introduced by Swinehart and Graber 2012, who, in their summary of Peery's 2012 contribution, speak of an effort to produce "not only a standard Navajo language but also standard Navajos"). Enlightened renovation can facilitate and even promote more heterogeneous habits, but attempts to do this run up against organised practices such as schooling which is "not set up to recognize multiple norms and mixed codes" (Jaffe 2007: 73 on Corsican).

A final, perhaps most obvious, aspect of language as properties, already hinted at in several places above, is that of market value. Ownership and rights to occupancy of a venue constitute a kind of capital. Those who occupy, or have preferential access to, the most highly valued venues are in a position of greater influence and power in the community at large. In this respect, Bourdieu's (1991) view of the impact of linguistic variety bears close resemblance that offered here. And indeed, Stroud's (2004) Bourdieuean analysis of language-ideological discourse in Sweden can be fairly easily interpreted in terms of access to, and rights of tenure on, the property (my term) of Swedish. However, the resemblance is not a perfect match. The market value of a particular language variety depends on the setting in which it is used (Blommaert (2010), so that, in order to maintain the resemblance at this point, we would need to invoke a meta-version of the metaphor in which languages are recognisable types of venue which can be found in many different polities, the precise value of each applying only in the polity in which each is located. ${ }^{10}$

\footnotetext{
${ }^{10}$ Bourdieu's account, like this one, situates language varieties in social space. And indeed, his analysis (1991: 82) of actors' self-awareness of "the value of [their] own linguistic products" can help to explain the motivations and struggles for choice of language at Europe College (see section 5 above). However, Bourdieu's emphasis is on the social and economic effects of the linguistic market in operation, so that his vision is of linguistic products as portable assets, deployed in actual social spaces. The intention of this paper, on the other hand, is to account for a wider range of languages-related phenomena and in this effort it depicts languages as real estate located in metaphorical social spaces.
} 


\section{Conclusion: some evaluative remarks}

I have presented in this paper the metaphor LANGUAGES ARE VENUES as a novel way of talking about varieties of language. I have demonstrated its utility for the study of language choice in 'secondary' plurilingual settings (i.e. those whose members hail from canonically monolingual 'primary' ones - see O'Driscoll 2001). I have also described other mappings of aspects of the source domain onto aspects of the target domain. Are there any language contact phenomena which are clearly not amenable to the venues metaphor? One candidate is code alternation (whether conceived of as code mixing or code-switching). It seems absurd to think of interactants teleporting back and forth between venues. Nevertheless, when the text of an encounter has a clear macro structure, this could be seen as the framing venue, into which habits and mannerisms indexing the other venue are inserted for effect (metaphorical switching). Meanwhile, mixed codes can be seen as venues in their own right, without boundaries or markers discernible to the outside world of course, since in the venues metaphor it is physical constructions like buildings and fences which allow the rest of the world to recognise 'a language'. This last suggestion stretches the metaphor by equating venues not just with recognised varieties of language but with ways of speaking in a more general sense. Such an extension is in keeping with the spirit of this essay, which is to find a place for languages in sociolinguistics which recognises their subjective existence without essentialising them. A venue doesn't have to have walls or fences.

Are there any prognostic disadvantages to venues metaphor? It might be argued that, in the battle for linguistic diversity, the venues metaphor is a poor substitute for the biomorphic metaphor. A listed building may seem less likely to activate protective emotions than an endangered species. This, as Cameron's (2007) analysis implies, is what the popular media and activists seem to think. Against this possibility, however, must be set the apprehension that a building is much easier to save than a species and that saving it does not give rise to misgivings about interfering where one shouldn't (i.e. with 'nature'). And in some cases, the thought of people being evicted from their own homes is especially emotive.

More importantly, the venues metaphor focuses attention where it should be focused; that is, on the plight of the users of a dilapidated language, thus helping to mitigate the tendency to orientalism in popular discourse on endangered languages identified by Cameron (2007) and the absurdity noted by Moore (2006: 298-299) in the endangered languages literature by which "last speakers are much more often lionized for the grammatical structures in their heads than for the eloquence of their utterances". The venues metaphor makes clear that battles for minority language rights should be battles for the comfort, security and empowerment of members of minority language groups. In some cases, there may be no special virtue for them in continuing to live in their old abode. If they can find a terrain and build a new one that suits them more, they will. The important point is that they own spaces where they feel at home.

Rejection of the biomorphic metaphor does not entail a rejection of links between linguistic diversity and biodiversity. There are some good arguments (e.g. SkutnabbKangas 2000: 91-97) to suggest that a decrease in the former is at least indirectly causative of diminution of the latter. But if, as Sampson (1980: 13-20) contends, the $19^{\text {th }}$ century ascendancy of the biological perspective on languages can be attributed in great 
measure to the success at that time of the biological theory of evolution, then the emergence in the last few decades of neo-Darwinian biology (e.g. genetics, socio-biology, evolutionary psychology) as a major scientific success-story might lead us to expect that a similar take on languages will seem even more obvious in the $21^{\text {st }}$ century than it did in the $20^{\text {th }}$ century. Indeed, it is perhaps invited by the way that biologists now talk of genes carrying 'information'. For this reason alone, as an antidote to contemporary tendencies to make biology the "master discourse" (Cameron 2007: 274) and contemporary attempts to "biologize the world ... to negate the social, cultural and political ...to make genetics the science of everything" (Pennycook 2004: 220), the venues metaphor is worth pursuing.

\section{Acknowledgement}

I would like to thank the two anonymous reviewers for several perspicacious comments.

\section{References}

Allard, Richard \& Richard Landry. 1986. Subjective ethnolinguistic vitality viewed as a belief system. Journal of Multilingual and Multicultural Development 7: 1-12.

Bell, Roger. 1976. Sociolinguistics: goals, approaches and problems. London: Batsford.

Blommaert, Jan. 2003. Commentary: a sociolinguistics of globalization. Journal of

Sociolinguistics 7(4): 607-623.

Blommaert, Jan. 2005a. Discourse: a Critical Introduction. Cambridge: Cambridge University Press. .

Blommaert, Jan. 2005b. Situating language rights: English and Swahili in Tanzania revisited. Journal of Sociolinguistics 9(3): 390-417.

Blommaert, Jan. 2008. Artefactual ideologies and the textual production of African languages. Language \& Communication 28(4): 291-307.

Blommaert, Jan 2010. The sociolinguistics of globalization. Cambridge: Cambridge University Press.

Bourdieu, Pierre. 1991. Language and Symbolic Power. Cambridge, Massachusetts: Harvard University Press.

Bragg, Melvyn. 2003. The Adventure of English. London: Hodder \& Stoughton.

Cameron, Deborah. 2007. Language endangerment and verbal hygiene: History, morality and politics. In Alexandre Duchêne \& Monica Heller (eds.), Discourses of Endangerment: Ideology and Interest in the Defence of Languages, 268-285. London: Continuum.

Cameron, Lynne. 1999. Identifying and describing metaphors in spoken discourse data. In L. Cameron \& G. Low (eds.), Researching and Applying Metaphor, 105-132. Cambridge:

Cambridge University Press.

Chand, Vineeta. 2009. [v]at is going on? Local and global ideologies about Indian English.

Language in Society 38: 393-419.

Crystal, David. 1988. The English Language. London: Penguin.

Crystal, David. 1997. The Cambridge Encyclopedia of Language ( $2^{\text {nd }}$ edn.). Cambridge:

Cambridge University Press.

Denison, Norman. 1977. Language Death or Language Suicide? International Journal of the Sociology of Language 12: 14-22.

Dorian, Nancy. 1987. The value of language-maintenance efforts which are unlikely to succeed.

International Journal of the Sociology of Language 68: 57-67.

Dorian, Nancy 1994. Choices and values in language shift and its study. International Journal of the Sociology of Language 110: 113-124. 
Dressler, Wolfgang \& Ruth Wodak-Leodolter. 1977. Language Death. International Journal of the Sociology of Language 12: 5-11.

Duchêne, Alexandre \& Monica Heller (eds.). 2007. Discourses of Endangerment: Ideology and Interest in the Defence of Languages. London: Continuum.

Edwards, John. 1986. Did English murder Irish? English Today 2: 7-12.

Errington, Joseph. 2008. Linguistics in a Colonial World: A Story of Language, Meaning and Power. Malden, Massachusetts: Blackwell.

Evans, Nicholas. 2010. Dying Words: Endangered Languages and What They Have to Tell Us. Oxford: Wiley-Blackwell.

Fasold, Ralph. 1984. The Sociolinguistics of Society. Oxford: Blackwell.

Fill, Alwin \& Peter Mühlhausler (eds.). 2001. The Ecolinguistics Reader: Language, ecology and environment. London: Continuum.

Fishman, Joshua. 1994. The truth about language and culture. International Journal of the Sociology of Language 109: 83-96.

Garafanga, Joseph. 2010. Medium request: Talking language shift into being. Language in Society 39: 241-270.

Giles, Howard, Richard Y. Bourhis \& Donald M. Taylor. 1977. Towards a theory of language in ethnic group relations. In Howard Giles (ed.), Language, Ethnicity and Intergroup Relations, 307-348. New York: Academic Press.

Green, John. 1994. Language status and political aspirations: the case of northern Spain. In M. M.

Parry, W. V. Davies \& R. A. M. Temple (eds.), The Changing Voices of Europe, 155-172. Cardiff: University of Wales Press.

Harris, Roy. 1990. On redefining linguistics. In Hayley Davis \& Talbot Taylor (eds.), Redefining Linguistics, 18-52. London: Routledge.

Harris, Roy. 1998. Introduction to integrational linguistics. Oxford: Pergamon.

Harrison, K. D. 2007. When Languages Die: The Extinction of the World's Languages and the

Erosion of Human Knowledge. Oxford: Oxford University Press.

House, Juliane. 2003. English as a lingua franca: A threat to multilingualism? Journal of Sociolinguistics 7(4): 556-578.

Hudson, R. A. 1996. Sociolinguistics ( $2^{\text {nd }}$ edn.) Cambridge: Cambridge University Press. Jaffe, Alexandra. 2007. Discourses of Endangerment: Contexts and consequences of essentializing discourses. In Alexandre Duchêne \& Monica Heller (eds.), Discourses of Endangerment: Ideology and Interest in the Defence of Languages, 57-75. London: Continuum. Lakoff, George \& Mark Johnson. 1980. Metaphors We Live By. Chicago: Chicago University Press.

Lakoff, George \& Mark Johnson. 1999. Philosophy in the Flesh. New York: Basic Books. Laponce, J. A. 1993. Do languages behave like animals? International Journal of the Sociology of Language 103: 19-30.

Leonard, Wesley Y. 2008. When Is an "Extinct Language" not Extinct? Miami: a Formerly Sleeping Language. In Kendall A. King, Natalie Schilling-Estes, Lyn Fogle, Jia Jackie Lou \& Barbara Soukup (eds.), Sustaining Linguistic Diversity: Endangered and Minority Languages and Language Varieties, 23-33. Washington DC: Georgetown University Press.

Le Page, Robert. 1988. Some premises concerning standardization of languages, with special reference to Caribbean creole English. International Journal of the Sociology of Language 71: 2536.

Lockwood, W. B. 1972. A Panorama of Indo-European Languages. London: Hutchinson. Makoni, Sinfree \& Alastair Pennycook (eds.). 2007. Disinventing and Reconstituting Languages. Clevedon, U.K.: Multilingual Matters.

May, Stephen. 2001. Language and minority rights: Ethnicity, nationalism and the politics of language. Harlow: Longman. 
Mazrui, Ali. 1975. The Political Sociology of the English Language: an African perspective. The Hague: Mouton.

McEwan-Fujita, Emily. 2011. Language revitalization discourses as metaculture: Gaelic in Scotland from the 18th to 20th centuries. Language \& Communication 31(1): 48-62.

Mesthrie, Rajend \& William Leap. 2009. Language Contact 1: Maintenance, Shift and Death. In Rajend Mesthrie, Joan Swann, Ana Deumert \& William L. Leap, Introducing Sociolinguistics $\left(2^{\text {nd }}\right.$ edn. $), 242-270$. Edinburgh: Edinburgh University Press.

Milroy, James \& Lesley Milroy. 1992. Social network and social class: toward an integrated sociolinguistic model. Language in Society 21(1): 1-26.

Milroy, Lesley. 1980. Language and Social Networks. Oxford: Basil Blackwell.

Moore, Robert E. 2006. Disappearing, Inc.: Glimpsing the sublime in the politics of access to endangered languages. Language \& Communication 26: 296-315.

Mühlhausler, Peter. 2011. Ecolinguistics, Linguistic Diversity, Ecological Diversity. In Sandra

Harding (ed.), The Postcolonial Science and Technology Studies Reader, 198-206. Duke

University Press.

Nagy, Naomi. 2011. Lexical change and language contact: Faetar in Italy and Canada. Journal of Sociolinguistics 15(3): 366-382.

Nettle, Daniel \& Romaine, Suzanne. 2000. Vanishing voices: The extinction of the world's

languages. Oxford: Oxford University Press.

O'Driscoll, Jim. 1999. Inter-national Communication and Language Choice in Modern Europe:

Vol 2, A Case Study and a Model. Ghent: Ghent University PhD thesis.

O'Driscoll, Jim. 2000. Sociolinguistics in a straitjacket: Review article of Spolsky 's

'Sociolinguistics '. Functions of Language 7(1): 133-148.

O’Driscoll, Jim. 2001. A face model of language choice. Multilingua 20(3): 245-268.

O'Driscoll, Jim. 2002a. Tyrannosaurus Rex? The supposed invasion of English in continental

Europe. In Gilian Moreira, \& Susan Howcroft (eds.), Línguas: Futuro Mais-Que-Perfeito? (Actas

do VI Encontro de APROLINGUAS), 255-280. Aveiro: Universidade de Aveiro.

O'Driscoll, Jim. 2002b. Hiding your difference: how non-global languages are being

marginalised in everyday interaction. Journal of Multilingual and Multicultural Development 22(6): 475-490.

Ó hIfearnáin, Tadgh. 2008. Endangering Language Vitality through Institutional Development: Ideology, Authority, and Official Standard Irish in the Gaeltacht. In Kendall A. King, Natalie Schilling-Estes, Lyn Fogle, Jia Jackie Lou \& Barbara Soukup (eds.), Sustaining Linguistic Diversity: Endangered and Minority Languages and Language Varieties, 113-128. Washington DC: Georgetown University Press.

Peery, Char. 2012. New Deal Navajo linguistics: Language ideology and political transformation. Language \& Communication 32: 114-123.

Pennycook, Alastair. 1994. The Cultural Politics of English as an International Language. London: Longman.

Pennycook, Alastair. 2004. Language policy and the ecological turn. Language Policy 3: $213-$ 239.

Phillipson, Robert. 1992. ELT - the native speaker's burden?. ELT Journal 46(1): 12-18.

Phillipson, Robert. 2008. Lingua franca or lingua frankensteinia? English in European integration and globalisation. World Englishes 27: 250-267.

Posner, Roland. 1991. Society, civilization, mentality: Prolegomena to a language policy for Europe. In Florian Coulmas (ed.), A Language Policy for the European Community: Prospects and Quandaries, 121-137. Berlin: Mouton de Gruyter.

Rampton, Ben. 1995. Crossing: Language and ethnicity among adolescents. Harlow: Longman. Rayfield, Donald. 1990. Saving the Basque language (review article). Multilingua 9(4): 413-423.

Sampson, Geoffrey. 1980. Schools of Linguistics. London: Hutchinson. 
Seargeant, Philip. 2009. Metaphors of possession in the conceptualisation of language. Language \& Communication 29: 383-393.

Shuck, Gail. 2004. Conversational performance and the poetic construction of an ideology.

Language in Society 33: 195-222.

Skutnabb-Kangas, Tove. 2000. Linguistic genocide in education or worldwide diversity and human rights? Mahwah, NJ: Lawrence Erlbaum.

Stewart, Wiilliam. 1968. A sociolinguistic typology for describing national multilingualism. In Joshua Fishman (ed.), Readings in the Sociology of Language, 531-545. The Hague: Mouton.

Stroud, Christopher. 2004. Rinkeby Swedish and semilingualism in language ideological debates: A Bourdieuean perspective. Journal of Sociolinguistics 8(2): 196-214.

Swales, John. 1997. English as Tyrannosaurus Rex. World Englishes 16(3): 373-382.

Swinehart, Karl \& Kathryn Graber. 2012. Tongue-tied territories: Languages and publics in stateless nations. Language \& Communication 32: 95-97.

Tardy, C. 2004. The role of English in scientific communication: lingua franca or Tyrannosaurus Rex? Journal of English for Academic Purposes 3(3): 247-269.

Tsitsipis, Lukas. 2006. Review of Viv Edwards, 2004, Multilingualism in the English-speaking World. Journal of Sociolinguistics 10(2): 255-258.

Vieru-Dimulescu, Bianca. 2008. Caractérisation et identification d'accents étrangers en français. Orsay: Université Paris-Sud 11PhD thesis.

Wardhaugh, Ronald. 1987. Languages: in competition: dominance, diversity and decline. Oxford: Basil Blackwell.

Watts, Richard J. 2011. Language myths and the history of English. New York: Oxford University Press.

Wicherkiewicz, Tomasz. 1995. Ethnic revival of the German minority in Poland. International Journal of the Sociology of Language 120: 25-38. 